\title{
The Basic Study on the Prepartion of Steel Slag Cement with Gas Quenching Steel Slag
}

\author{
Yue Long ${ }^{*}, 1$, Liangyu Yue ${ }^{2}$, Gaoliang $\mathrm{Li}^{1}$, Yunbo Lei ${ }^{1}$ and Shaoning Wang ${ }^{3}$ \\ ${ }^{I}$ College of Metallurgy and Energy, Hebei United University, Tangshan Hebei 063009, China \\ ${ }^{2}$ Tangshan Labor Technician College, Tangshan Hebei 063009, China \\ ${ }^{3}$ Tangshan Iron and Steel Ltd. Tangshan Hebei 063009, China
}

\begin{abstract}
Through experiment study of the contents of gas quenching steel slag f-CaO, mineral composition, grindability, the physical property and hydrate mechanics of steel slag cement made of gas quenching steel slag, as well as through analysis of gas quenching steel slag cement economic benefit and brief introduction to the granulation technology and its feature. The results show that: the ratio of $\mathrm{f}-\mathrm{CaO}$ in the initial gas quenching steel slag which is smaller than $2 \mathrm{~mm}$ is less than $2.7 \%$, while the ratio $\mathrm{f}-\mathrm{CaO}$ in the gas quenching steel slag after pulverization and smaller than $2 \mathrm{~mm}$ is less than $1.3 \%$; the main mineral content of it is $\mathrm{C}_{2} \mathrm{~S}, \mathrm{C}_{3} \mathrm{~S}$, calcium alumino ferrite, a small quantity of RO phase, $\mathrm{f}-\mathrm{CaO}$ and $\mathrm{MgO}$, etc. The grindability of gas quenching steel slag is better than heat-stew steel slag; And cement mixed with $20 \%$ of gas quenching steel slag can be used to produce portland cement (Grade 52.5), if the addition of gas quenching steel slag is $40 \%$, which can produce P.S.A32.5 cement. Therefore, using gas quenching steel slag to produce cement will be of great economic benefit.
\end{abstract}

Keywords: Granulation, f-CaO, strength, grindability index, economic benefit.

\section{INTRODUCTION}

The output of crude steel in China in 2009 reached 508 million $\mathrm{t}$ and the production of steel slag has more than 50 million t. But the utilization of steel slag of domestic currently is still very low, resulting in a large number of steel slag accumulation, It not only takes up a lot of land resources and pollute the environment seriously, but also wastes lots of resources. There are a series of methods for Steel slag treatment [1] but gas quenching is a method which can combine comprehensive treatment of steel-making slag and integrated utilization of key resources. To meet the development of low carbon economy-based society, it is important to investigate the later development of gas quenching steel slag.

\section{THE BREF INTRODUCTION OF THE TECHNICS OF GAS QUENCHING STEEL SLAG}

The processing of making gas quenching steel slag is to poured the liquid steel slag from the converter which is impact crushed by nitrogen gas jet and then granulated in the gas quenching device, at the same time the heat has been exchanging. Approximately $97 \%$ of granulated steel slag was less than $2 \mathrm{~mm}$ in granularity. The granularities of blasted gas quenching steel slag are distributed as in Table 1. After the steel slag is impacted by high-pressure and high-speed air flow, its specific surface area can be increased. The rapid cooling technology of liquid steel slag can be made when the temperature drops below $500^{\circ} \mathrm{C}$ as the steel slag is $15 \mathrm{~m}$

*Address correspondence to this author at the College of Metallurgy and Energy, Hebei United University, Tangshan Hebei 063009, China; Tel: +860315-2592158; Fax: +86-0315-2592155; E-mail: longyue@heut.edu.cn away the nozzle within 1s. Fig. (1) shows a gas quenching graining device of liquid steel slag.

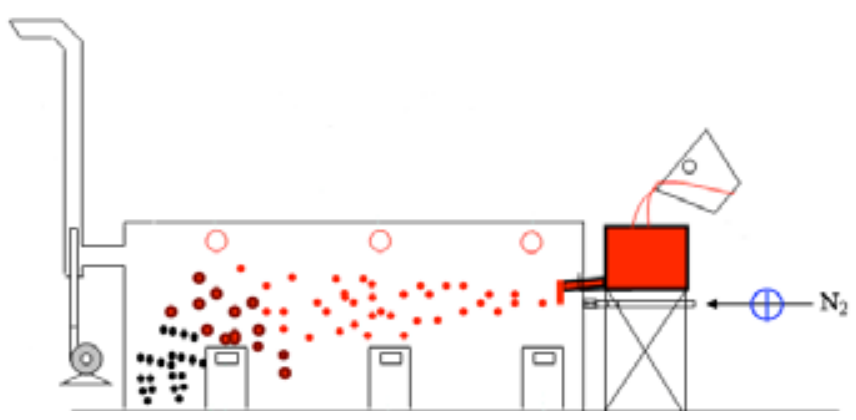

Fig. (1). Gas quenching graining device of liquid steel slag.

Table 1 shows the particle size distribution of gas quenching steel slag where we can see that the sizes of steel slag particles are mainly $1-2 \mathrm{~mm}$ and $0.1-0.5 \mathrm{~mm}$. The results can be shown in Fig. (2).

As taking the rapid nitrogen cooling technology, there is difference in chemical composition between heat-stew and gas quenching steel slag. Having tested the steel slag of Tangshan Iron and Steel Plate Material Co., Ltd, it can be seen the chemical composition in Table 2.

Table 2 shows that as the increase of the specific surface area of steel slag after granulated most of $\mathrm{FeO}$ in steel slag particles were oxidized to $\mathrm{Fe}_{2} \mathrm{O}_{3}$, the $\mathrm{CaO} \cdot \mathrm{FeO}$ and other substances will be reduced. Other elements are basically unchanged. The true density of gas quenching steel slag is about $3.55-3.65 \mathrm{~g} / \mathrm{cm}^{3}$, the packing density about $2.22 \mathrm{~g} / \mathrm{cm}^{3}$. 
Table 1. Gas Quenching Steel Slag Particle Size Distribution

\begin{tabular}{|l|c|c|c|c|c|c|c|c|}
\hline Diameter $/ \mathbf{m m}$ & $>3$ & $2-3$ & $1-2$ & $0.6-1$ & $0.45-0.6$ & $0.1-0.45$ & $0.08-0.1$ & $<0.08$ \\
\hline Percentage/\% & 1.45 & 2.11 & 39.02 & 10.68 & 15.35 & 26.79 & 1.11 & 3.01 \\
\hline
\end{tabular}

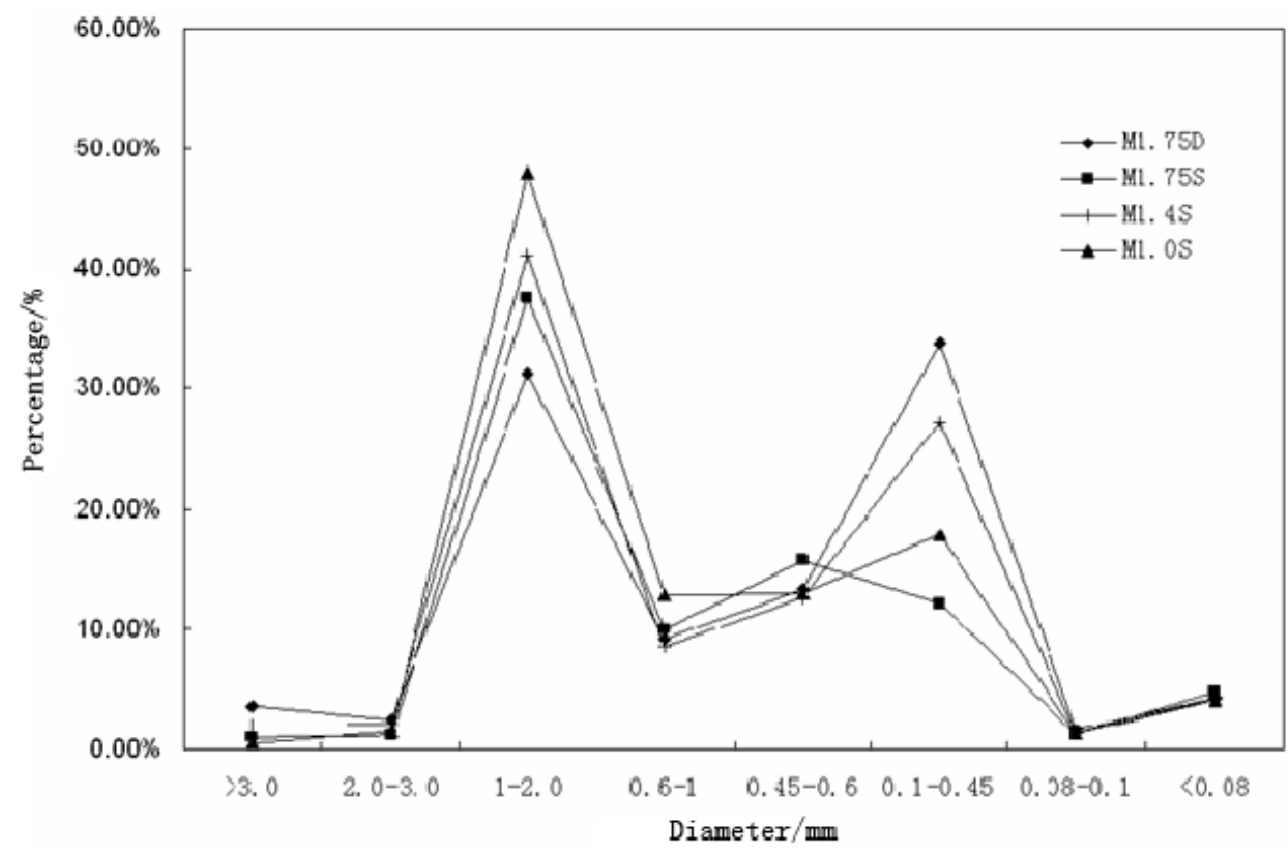

Fig. (2). Size distribution of gas quenching steel slag.

Table 2. Chemical Composition of Gas Quenching Steel Slag and Heat-Stew Steel Slag

\begin{tabular}{|c|c|c|c|c|c|c|c|c|}
\hline Sample & $\mathbf{T F e}$ & $\mathbf{m F e}$ & $\mathbf{F e}_{2} \mathbf{O}_{3}$ & $\mathbf{F e O}$ & $\mathbf{S i O}_{2}$ & $\mathbf{C a O}$ & $\mathbf{M g O}$ & $\mathbf{S}$ \\
\hline \hline Gas Quenching Steel Slag & 17.12 & 2.40 & 24.02 & 2.99 & 13.67 & 44.94 & 8.42 & 0.0083 \\
\hline Heat-stew Steel Slag & 19.22 & 1.29 & 7.59 & 19.44 & 12.41 & 46.87 & 7.84 & 0.0058 \\
\hline
\end{tabular}

\section{DETERMINATION AND ANALYSIS OF F-CAO IN STEEL SLAG}

\subsection{Distribution Regularity of f-CaO of Gas Quenching Steel Slag with Different Particle Diameters}

The stability of steel slag cement can be affected by f$\mathrm{CaO}$ in steel slag, the content of which will directly affect the later utilization. We do some comparative tests on the steel slag by analysis pure calcium oxide while determining the content of $\mathrm{f}-\mathrm{CaO}$ by ethylene glycol-EDTA [2, 3] complexometric titration to eliminate the effect on $\mathrm{Ca}^{2+}$ caused by $\mathrm{Fe}^{2+}, \mathrm{Al}^{3+}, \mathrm{Mn}^{2+}$. Through the gas quenching treatment on converter steel slag in Tangshan Iron and Steel
Plate, we find that the difference is obvious about the content of $\mathrm{f}-\mathrm{CaO}$ in different size of gas quenching residue and a proportional relation exists between the content of the $\mathrm{f}-\mathrm{CaO}$ in gas quenching steel slag and particle size. The results were shown in Table $\mathbf{3}$.

Table 3 shows that the content of $\mathrm{f}-\mathrm{CaO}$ of the steel slag is $6.82 \%$, of which the particle size is less than $2 \mathrm{~mm}$ and it reaches $2.63 \%$ when the particle size fall in between $1 \mathrm{~mm}$ and $2 \mathrm{~mm}$. As to the steel slag whose particle size are $0.6 \sim 1 \mathrm{~mm}$ and $0.15 \sim 0.6 \mathrm{~mm}$, the $\mathrm{f}-\mathrm{CaO}$ contents are respectively $1.85 \%$ and $1.65 \%$. The result is accurate and meet the measurement standards with $\mathrm{f}-\mathrm{CaO}<3 \%$. One of the reasons of making the content of $\mathrm{f}-\mathrm{CaO}$ reduced is that

Table 3. f-CaO Content of Different Particle Size of Gas Quenching Steel Slag

\begin{tabular}{|c|c|c|c|c|c|c|c|}
\hline \multirow{2}{*}{$\begin{array}{c}\text { Gas Quenching Steel Slag Sample } \\
>2 \mathrm{~mm}\end{array}$} & \multicolumn{5}{|c|}{ f-CaO Measurements Numerical (w/\%) } & \multirow{2}{*}{$\begin{array}{c}\text { Average Numerical (w/\%) } \\
6.82\end{array}$} & \multirow{2}{*}{$\begin{array}{c}\text { Relative Standard Deviation (w/\%) } \\
1.61\end{array}$} \\
\hline & 6.88 & 6.70 & 6.94 & 6.86 & 6.70 & & \\
\hline $1-2 \mathrm{~mm}$ & 2.65 & 2.65 & 2.57 & 2.69 & 2.61 & 2.63 & 1.74 \\
\hline $0.6-1 \mathrm{~mm}$ & 1.84 & 1.80 & 1.88 & 1.88 & 1.84 & 1.85 & 1.80 \\
\hline $0.15-0.6 \mathrm{~mm}$ & 1.67 & 1.63 & 1.63 & 1.71 & 1.59 & 1.65 & 2.77 \\
\hline
\end{tabular}


there is not enough time for calcium silicate to decomposition which caused by flash cooled in a short time and the solidification of the gas quenching steel slag. The f$\mathrm{CaO}$ content will be lower with the smaller steel slag particles and the faster cooling, The other reason is that with the increasing of the content of $\mathrm{Fe}_{2} \mathrm{O}_{3}$, part of $\mathrm{f}-\mathrm{CaO}$ is consumed in the reaction $\mathrm{Fe}_{2} \mathrm{O}_{3}+2 \mathrm{CaO}=2 \mathrm{CaO} \cdot \mathrm{Fe}_{2} \mathrm{O}_{3}$.

\subsection{Distribution Regularity of f-CaO of Atomized Gas Quenching Steel Slag with Different Particle Diameters}

Respectively put the gas quenching steel slag with particle diameter between $0.15 \mathrm{~mm}$ and $0.6 \mathrm{~mm}$ and between $1 \mathrm{~mm}$ and $2 \mathrm{~mm}$ into muffle furnace and heat them to $300^{\circ} \mathrm{C}$, $400^{\circ} \mathrm{C}$ and $500^{\circ} \mathrm{C}$. Take them out and conduct interstitial watering, and then use sensible heat to carry out atomization and digestion for the $\mathrm{f}-\mathrm{CaO}$ in the gas quenching steel slag. Let the digested samples to be measured cool down and then put them into the drying oven to dry them for 6 hours. Afterwards, use a planetary ball mill to grind them until their granularity was less than $0.074 \mathrm{~mm}$, and finally used glycolEDTA compleximetry to measure the content of the f-CaO in the samples to be measured, which was shown in Table 4. and the $\mathrm{f}-\mathrm{CaO}$ content shows an obvious decrease in the process, during which the temperatures rises to $500^{\circ} \mathrm{C}$ from $300^{\circ} \mathrm{C}$. Compared with Table 3 , at $500^{\circ} \mathrm{C}$, the $\mathrm{f}-\mathrm{CaO}$ content in the particles diameter of $0.15-0.6 \mathrm{~mm}$ and of $1-2 \mathrm{~mm}$ respectively decreased by $82 \%$ and $77 \%$, indicating that the free $\mathrm{CaO}$ of the gas quenching steel slag will be atomized and digested more thoroughly at high temperature. The shorter the particle diameter of the gas quenching slag is, the lower $\mathrm{f}-\mathrm{CaO}$ content results under atomization and digestion. As shown in Table 1, the gas quenching steel slag with particle diameter $<2 \%$ almost account for $97 \%$, therefore, after atomization and digestion, if the gas quenching steel slag are used as the cement admixture, its f-CaO content will not cause any bad impact on the stability of the gas quenching steel slag cement. Besides, the test shows that the steel slag cement prepared with gas quenching steel slag has excellent stability.

\subsection{Analysis on X-ray Diffraction (RXD) of Gas Quenching Steel Slag}

The D/MAX2500PC X-ray diffractometer produced by Japanese Rigaku International Corp, which was used to

Table 4. Content of f-CaO of Atomized Gas Quenching Slag with Different Particle Diameters

\begin{tabular}{|c|c|c|c|c|c|c|c|c|}
\hline \multirow{2}{*}{$\begin{array}{c}\text { Samples of Gas Quenching Slag } \\
0.15-0.6 \mathrm{~mm} \\
\end{array}$} & \multirow{2}{*}{$\begin{array}{c}\text { Atomization Temperature }\left({ }^{\circ} \mathbf{C}\right) \\
500 \\
\end{array}$} & \multicolumn{5}{|c|}{ Measured Value of f-CaO (w/\%) } & \multirow{2}{*}{$\frac{\text { Mean Value }(\mathrm{w} / \%)}{0.37}$} & \multirow{2}{*}{$\frac{\operatorname{RSD}(\mathbf{w} / \%)}{1.42}$} \\
\hline & & 0.32 & 0.44 & 0.36 & 0.4 & 0.32 & & \\
\hline $0.15-0.6 \mathrm{~mm}$ & 400 & 0.93 & 0.98 & 0.98 & 0.97 & 0.85 & 0.94 & 5.88 \\
\hline $0.15-0.6 \mathrm{~mm}$ & 300 & 1.22 & 1.08 & 1.14 & 1.18 & 1.06 & 1.13 & 5.89 \\
\hline $1-2 \mathrm{~mm}$ & 500 & 0.48 & 0.47 & 0.49 & 0.51 & 0.41 & 0.47 & 7.98 \\
\hline $1-2 \mathrm{~mm}$ & 400 & 0.73 & 0.85 & 0.93 & 0.81 & 0.77 & 0.81 & 9.41 \\
\hline $1-2 \mathrm{~mm}$ & 300 & 1.22 & 1.18 & 1.3 & 1.26 & 1.34 & 1.26 & 5.02 \\
\hline
\end{tabular}

Table 4 shows that every f-CaO content of the atomized and digested gas quenching steel slag was less than $1.5 \%$, analyze the typical minerals in the gas quenching slag. Please see Fig. (3) for the XRD spectrum analysis.

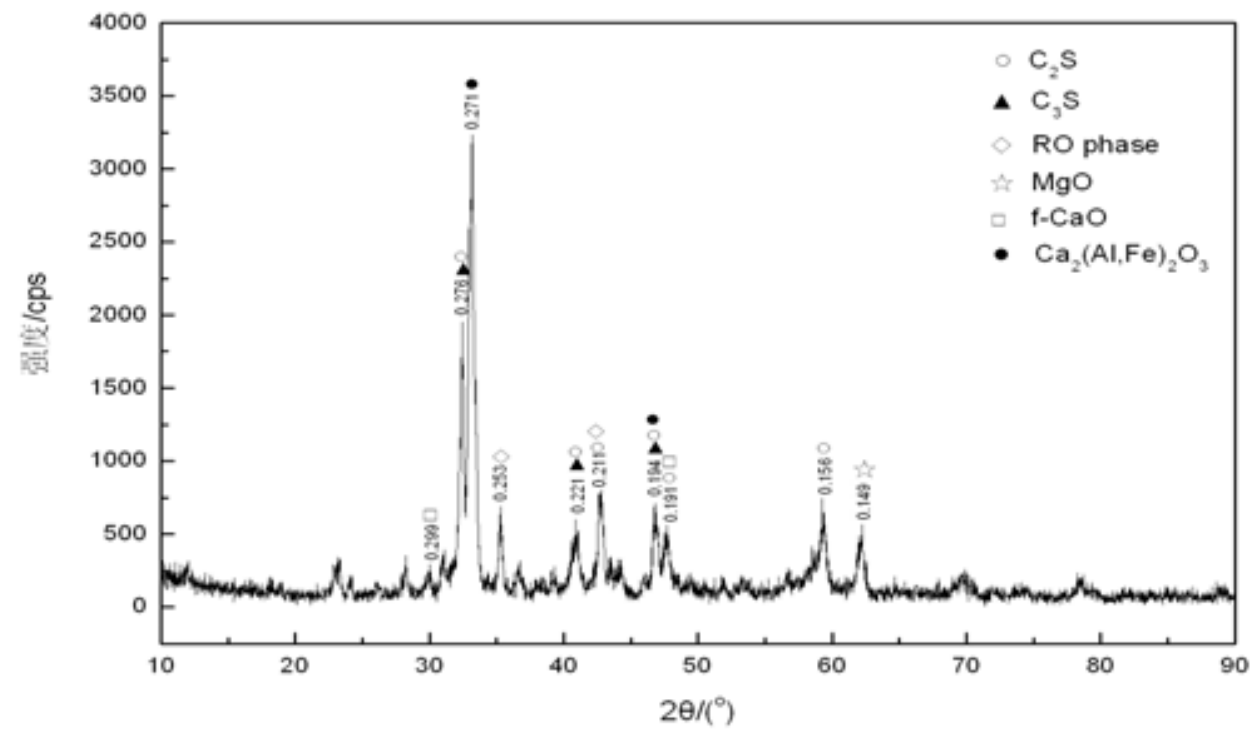

Fig. (3). XRD pattern of the gas quenching steel slag. 
As shown in Fig. (3), the diffraction peak of gas quenching steel slag was relatively single. Except higher diffraction peaks at the places where the diffraction angles $\left(2 \theta=32.5^{\circ}\right.$ and $\left.2 \theta=32.9^{\circ}\right)$ were respectively corresponding to the interplanar spacings $(\mathrm{d}=0.271 \mathrm{~nm}$ and $\mathrm{d}=0.194 \mathrm{~nm})$, other diffraction peaks had lower intensity and narrower peak surface, which indicated that the main minerals in the gas quenching steel slag were $\mathrm{C}_{2} \mathrm{~S}, \mathrm{C}_{3} \mathrm{~S}$, calcium ferroalumnates and a few $\mathrm{f}-\mathrm{CaO}$ and $\mathrm{f}-\mathrm{MgO}$. Therefore, if used as the cement admixture, the gas quenching steel slag meets the potential condition as the raw material of cement.

\section{ANALYSIS ON THE PERFORMANCE OF INTERGRINDING OF STEEL SLAG}

The grindability of steel slag has a direct bearing on the economic benefits of the cement industry because 60\%-70\% power which consumed by cement producing is used for crushing and grinding raw materials and steel slag has to be doped as admixture because of its high cementing property [4-6]. Compared to the heat-stew steel slag processed by conventional treatment, the average particle size is much smaller and about $98 \%$ of which is less than $3 \mathrm{~mm}$. Compared to the grindability of the steel slag with different Intensity of cooling in the same experimental conditions. The result was shown in Table 5 .

$\mathrm{K}_{0}=\mathrm{S} / \mathrm{S}_{1}$.

$\mathrm{S}$ - the specific surface of material in the same powder grinding time, $\mathrm{m}^{2} / \mathrm{kg}$

$\mathrm{S}_{1}$ - the specific surface of standard sands in the same powder grinding time, $\mathrm{m}^{2} / \mathrm{kg}$

Table 5. Relationship of steel Slag Easy Grinding

\begin{tabular}{|c|c|c|c|c|c|}
\hline \multirow{2}{*}{ Grinding Time /min } & \multicolumn{3}{|c|}{ Specific Surface Areas / $\mathbf{m}^{2} / \mathbf{k g}$} & \multicolumn{2}{c|}{ Relative Grindability Index } \\
\cline { 2 - 6 } & Standard Powder & Gas Quenching Steel Slag & Heat-Stew Steel Slag & Gas Quenching Steel Slag & Heat-stew Steel Slag \\
\hline \hline 30 & 252.55 & 273.32 & 276.11 & 1.08 & 1.09 \\
\hline 50 & 397.10 & 394.01 & 348.85 & 0.99 & 0.88 \\
\hline 70 & 535.17 & 499.05 & 400.18 & 0.93 & 0.75 \\
\hline 90 & 667.37 & 606.19 & 414.58 & 0.91 & 0.62 \\
\hline
\end{tabular}

The Fig. (4) shows the relationship of relative grindability index of steel slag varying with time.

Since the same experimental conditions, the degree of fineness of the two materials is determined by its physical properties at the same powder grinding time. The grindability of materials will be better with less influencing factors on grinding during the test. The higher specific surface and the larger specific surface ratio of standard sand at the same grinding time Otherwise it won't be so. From the graph it was clear that the relative grindability index of gas quenching steel slag was significantly higher than the slow cooling steel slag. As the cement admixture, the specific surface of gas quenching steel slag is $350 \mathrm{~m}^{2} / \mathrm{kg}$ in accordance with the national standard. It's better to grind for 50 minutes to get higher relative grindability index. As the grindability of gas quenching steel slag is much better than heat-stew steel slag and 60\%-70\% energy consumed in grinding process, it can bring enormous economic benefits by saving the grinding cost for the cement industry.

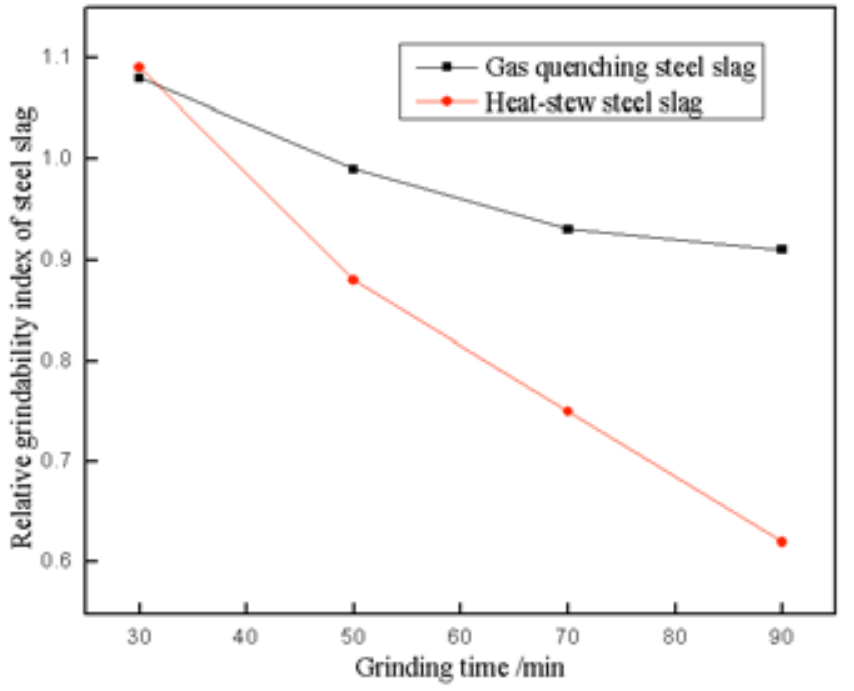

Fig. (4). Relationship easy steel slag grinding index changing with time.

\section{ANALYSIS OF CEMENT PERFORMANCE PRODUCED BY GAS QUENCHING STEEL SLAG}

With the dicalcium silicate, calcium aluminoferrite and the solid solution of magnesium iron phase as the main Component, there is still little $\mathrm{C}_{3} \mathrm{~S}, \mathrm{f}-\mathrm{CaO}, \mathrm{MgO}$ and $\mathrm{RO}$ phase contained in steel slag. Steel slag can be called "overburning silicate clinker", because it has similar mineral composition with silicate clinker and the formation character 
hydrating can be totally absorbed by the active component Provided by gas quenching steel slag, resulting in shortened setting time of steel slag cement.

The free calcium oxide in steel slag has been the main factor which affect stability of cement. Table $\mathbf{3}$ shows that the content of $\mathrm{f}-\mathrm{CaO}$ is much higher when the particle size of gas quenching steel slag more than $2 \mathrm{~mm}$ while the content of $\mathrm{f}-\mathrm{CaO}$ will be less than $3 \%$ when the size is less than $2 \mathrm{~mm}$ and $97 \%$ of which are used to produce the cement. It will not affect the stability of the cement if the content of f-CaO is less than $4.5 \%$. Therefore, the $\mathrm{f}-\mathrm{CaO}$ in gas quenching steel slag will not have any effect on the stability. According to the provision of $\mathrm{YB} / \mathrm{T}$ 022-92, the content of $\mathrm{Fe}$ in steel slag must be less than $1 \%$ [8], but with the increasing dosage, the content of $\mathrm{Fe}$ in micro-powder of gas quenching steel slag gradually increased. It can lead to unqualified stability of the cement when the contend is beyond $60 \%$. Though most of the $\mathrm{Fe}$ can be removed via magnetic concentration and because of the gas quenching residue particle size is relatively small, it's difficult to carry out magnetic concentration under laboratory conditions. As the gas quenching of steel slag can overcome the poor stability caused by the $\mathrm{f}-\mathrm{CaO}$, it is feasible in theory to gain perfect stability by improving the magnetic concentration process.

A series of test of $3 \mathrm{~d}, 28 \mathrm{~d}$ have been carried out respectively on the cement strength of gas quenching steel slag with different dosage. The experimental result is shown in Figs. $(\mathbf{5}, \mathbf{6})$.

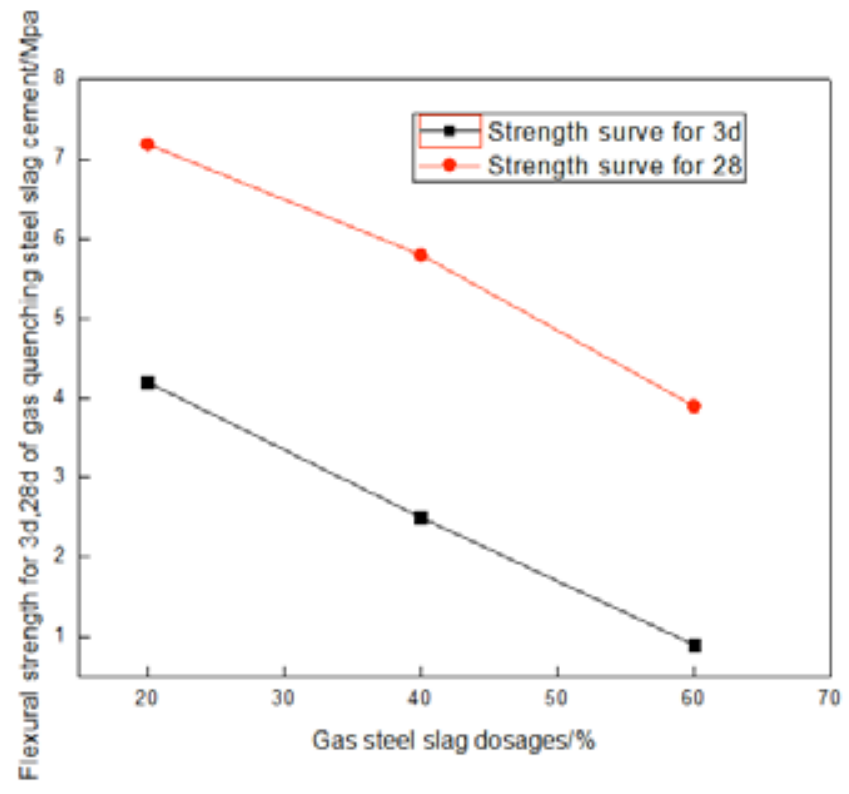

Fig. (5). Steel slag cement flexural strength.

Table 6. Comparison of Steel Slag Easy Grinding
As shown in Figs. (5, 6), for the cement with $20 \%$ admixture of steel slag, its strength reaches the strength standard of Portland cement (Grade 52.5) and its 28d compressive strength surplus reaches 15.2PMa, with the compressive strength in later period increasing faster. With the increase of the addition of steel slag, the strength of gas quenching steel slag cement shows relatively faster decrease. But when the addition of steel slag is $40 \%$, the strength of the gas quenching steel slag cement can reach the standard of slag Portland cement (Grade 32.5) and its 28d compressive strength surplus reaches 19.8PMa. Therefore, the gas quenching steel slag cement meets the production requirements in term of strength. Further researches show that it is feasible to produce high-grade cement with large admixture in theory.

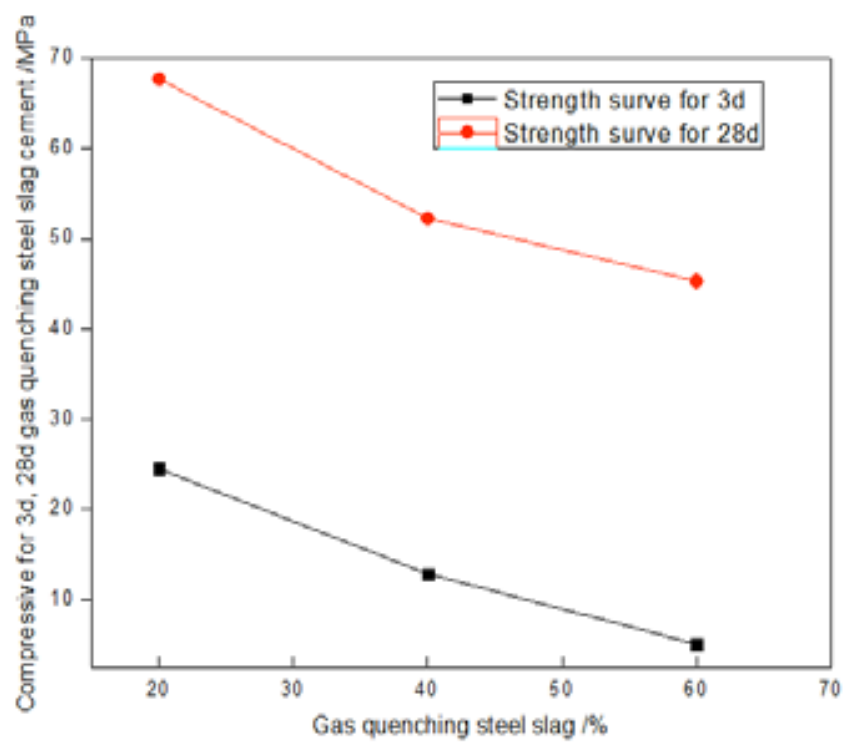

Fig. (6). Steel slag cement compressive strength.

\section{ANALYSIS OF ECONOMIC BENEFITS FOR GAS QUENCHING STEEL SLAG AS A CEMENT ADMIXTURE}

As a cement admixture, the mill feed size and the grindability of slag directly affect the grinding efficiency, therefore, reducing the mill feed size appropriately and improving its grindability can not only increase production but also can reduce the energy consumption. According to the literature [9] records, when crushing and ball-milling the materials with the cone crusher and ball mill-type crusher, it is more economical to keep the mill feed size $2 \mathrm{~mm}$ into the ground. Because the electric efficiency of the crusher is about $30 \%$, while ball crusher is only $1 \%-3 \%, 7 \%-8 \%$ maximum. Thus a reduction in size to the mill, but also can reduce the power consumption of grinding and crushing mill

\begin{tabular}{|c|c|c|c|c|}
\hline \multirow{2}{*}{ Sample } & \multicolumn{4}{|c|}{ Grindability Results } \\
\cline { 2 - 5 } & $\mathbf{W}_{\mathbf{i}}(\mathbf{K}$ wh/t) $)$ & $\mathbf{G}_{\mathbf{i}}(\mathbf{g} / \mathbf{r})$ & $\begin{array}{c}\mathbf{8 0 \%} \text { Finished Products Through the Sieve`s Size } \\
(\mathbf{u m})\end{array}$ & $\begin{array}{c}\text { 80\% Products Through the Sieve`s Size } \\
\text { (um) }\end{array}$ \\
\hline \hline Gas Quenching Steel Slag & 25.9 & 0.64 & 70 & 2500 \\
\hline Heat-stew Steel Slag & 30.3 & 0.49 & 63 & 2500 \\
\hline
\end{tabular}


of the total unit power consumption. As for the gas quenching steel slag, the average particle size of $<2 \mathrm{~mm}$ almost accounted to $97 \%$, almost no fragmentation, compared to ordinary steel slag, the only increase production and reduce overall power consumption.

Table 6 shows comparison of steel slag easy grinding.

Therefore, if gas quenching steel slag as cement mixing materials, not only to save grinding energy consumption, but can guarantee the quality of the huge economic efficiency.

\section{CONCLUSIONS}

It can be concluded by studying the performance of gas quenching steel slag

1. About $97 \%$ of the gas quenching steel slag in the f$\mathrm{CaO}$ content is lower than $2.7 \%$.

2. The grinding characteristics of gas quenching steel slag is superior to heat-stew steel slag, the specific surface areas can reach $350 \mathrm{~m}^{2} / \mathrm{kg}$ in 50 minutes

3. From the analysis of stability and performance, the mixing amount in the gas quenching steel slag cement should be controlled within $60 \%$.

4. The cement with $20 \%$ admixture of steel slag, its strength reaches the strength standard of Portland cement (Grade 52.5), but when the addition of steel slag is $40 \%$, the strength of the gas quenching steel slag cement can reach the standard of slag Portland cement (Grade 32.5)
5. The production of gas quenching steel slag cement has a huge economic benefit with the result of saving nearly $4 \mathrm{Kwh}$ power per ton of steel slag grinding.

\section{ACKNOWLEDGMENTS}

This work is supported by Key Basic Research Project of Science and Technology Department of Hebei Province (No.10965633D) and Youth Foundation Project of Education Department of Hebei Province (No.2010135).

\section{REFERENCES}

[1] Chen MZ, Zhou MK, Lun YX. et al. Research on high added value utilization of steel slag. China Mining Magazine 2006; 15: 79-83.

[2] $\mathrm{Yu} \mathrm{JH}, \mathrm{Wu} \mathrm{X}$. Continuous determination of free Calcium Oxide and Magnesium Oxide by conductometric Method. Anal Chem 1998; 75-77.

[3] Le XH, Zhu WX, Zhang YS. Using the value of $\mathbf{J}$ method for determination steel slag f-CaO. Res Iron Steel 1989; 5: 77-78.

[4] Shan ZF. The state of treatment technique and comprehensive unilization to steel slag in China and abroad. Ind Saf Dust Control 2000; : 27-32.

[5] Liu H, Hou XK, Xu PJ. et al. Analysis on character of granulated blast furnace slag powder ground by vertical mill and ball mill. J Build Mater 2008; 11: 319-322.

[6] Wu Y, Li J. Effect of superfine slag powder on HPC properties. J Mater Sci Technol 2003; :87-90.

[7] Meng HD, Liu L. Stability processing technology and application prospect of steel slag. Steelmaking 2009; 26:74-78.

[8] Zhang TS, Liu FT, Wang JW. et al. Recent development of steel slag stability and activating activity. Bull Chin Ceram Soc 2007; 26:981-982.

[9] Zhang SQ, Yang QB, Wu XL. Strength characteristics of new slag cement in china. In Fifth International Proceedings of Symposium on the Cement and Concrete Conference 2002; 510-514. 